\title{
Effect of Internally Generated Revenue on Budget Implementation in Ekiti State
}

\author{
Olaoye Clement Olatunji ${ }^{1}$ \& Olugbamiye Olorunleke Dominic ${ }^{1}$ \\ ${ }^{1}$ Department of Accounting, Faculty of Management Sciences, Ekiti State University, Ado Ekiti, Nigeria \\ Correspondence: Olugbamiye Olorunleke Dominic, Department of Accounting, Faculty of Management Sciences, Ekiti \\ State University, Ado Ekiti, Nigeria.
}

Received: January 10, 2019

Accepted: March 12, 2019

Available online: May 6, 2019

doi:10.11114/afa.v5i2.4253

URL: https://doi.org/10.11114/afa.v5i2.4253

\begin{abstract}
The study examined the effect of internally generated revenue on budget implementation in Ekiti State. Specifically the study analyzed trends of components of internally generated revenue in Ekiti state including taxes, fines \& fees, licenses, earnings and sales, interest and dividend, evaluated the relative impact of internally generated revenue components on budget implementation, and also analyzed the causal relationship between internally generated revenue components and budget implementation in Ekiti state. The study made use of time series secondary data sourced from the annual budget of Ekiti state for a period of ten years spanning form 2007 to 2016. Data collated were analyzed with trend analysis, descriptive analyzes, correlation analysis, ordinary least square regression analysis and granger causality analysis. Result revealed that components of internally generated revenue in Ekiti State has increased considerably over the last ten years, relative impact of taxes on expenditure implementation stood at 4.754741( $\mathrm{p}=0.6232>0.05)$, relative impact of fines and fees on expenditure implementation stood at $0.354370(\mathrm{P}=0.9624>0.05)$, relative impact of licenses on expenditure implementation stood at $1.312830(\mathrm{p}=0.8427>0.05)$, relative impact of earnings and sales on expenditure implementation stood at $0.166495(\mathrm{p}=0.9877>0.05)$, relative impact of interest and dividend on expenditure implementation stood at $2.478020(\mathrm{p}=0.7849>0.05)$, and that there is no causal relationship between components of internally generated revenue and expenditure implementation in Ekiti state. It was concluded that though internally generated revenue components identified in the study trended predominantly upwards over the last ten years, their relative impact on the level of budget implementation is not significant. More so the study established that there is no causal relationship between components of internally generated revenue and budget implementation. The study therefore recommended that Ekiti State Government should device a new framework for boosting the level of internally generated revenue in the state, in such a way that potentials and resources lying unused in the state will be harmonize to foster effective and efficient budget implementation. Government in the state should devise an Information Technology driven revenue mobilization mechanisms to ensure that revenue generated from all sources such as taxes, fines $\&$ fees, licenses, earnings \& sales, interest and dividend are monitored and properly accounted for, also there is need for reduction of external borrowing that can culminate into excessive deduction in the statutory allocation, which could dampen the capacity of sustaining efficient level of budget implementation in the state.
\end{abstract}

Keywords: internal generated revenue, budget implementation, taxes, statutory allocation

\section{Introduction}

Budget implementation is a phenomenon of global interest, triggering unending debated both in developed and developing countries alike. There is growing concern on the issue of poor budget implementation at federal, state and local government levels especially in third world countries. Reason for this ever increasing concern of budget implementation could stems from the central role of budgeting in the accomplishment of economic and non-economic governmental goals (Samuel \& Wilfred, 2009; Onaolapo \& Olaoye, 2013). As a comprehensive outline of activities geared toward a predetermined objectives, budgeting entail both revenue and expenditure projection which require effective implementation if the desired end must be attained. The attainment of projections ultimately explains the place of budget implementation. Public budget is a tool used by government for economic intervention, as such its implementation in crucial for ensuring economic stability and sustaining economic growth and development (Asimiyu \& Saidi 2015). The importance of budget implementation needs not belabored, especially in developing countries where there is growing need for investment in capital overhead-a sine-qua-non for sustaining improved infrastructural 
facilities necessary for expansion of business activities, and attraction of foreign investment, not to undermine its indelible impact on standard and quality of lives (Alesina, Hausmann, Hommes \& Stein 1996). Effect of poor budget implementation in Ekiti state has eaten deep into the level of productivity, and this had resulted in the state been enlisted as one of the poorest state in the country (National Bureau of statistics, 2012). It has also left most of the natural resources of the state unharnessed (Olowolaju, Ajibola, Ishola, \& Falayi, 2014). Poor budget implementation in Ekiti state is attributed to the inability of the state to generate enough internal revenue to finance key government spending both capital and recurrent. As observed by Omotoso (2009), over-dependence on statutory allocation due to low capacity to generate revenue within the state has been a major bane hampering budget implementation in Ekiti state. The menace of poor budget implementation in Ekiti state had hither-to dampened ability of government budgeting to engender rapid development needed to provoke high standard of living. The reality in Ekiti state reflect the affirmation of Arogundade and Olaoye (2016) that actual revenue generated within a state goes a long way in the determination of budget performance and implementation needed to trigger rapid development. In Nigeria the discourse of budget implementation/performance had drawn sizeable empirical attention over the years (Ugoh and Ukpere (2009); Ojo (2012); Obara (2013); Onaolapo and Olaoye (2013); Edame and Ejue (2013); Okpala (2014); Ibanichuka and Oyadonghan (2014); Ogujiuba and Ehigiamusoe (2014); Ekhator and Chima (2015), Arogundade and Olaoye (2016), Oladele and Olaoye (2016); Onyiah, Ezeamama, Ugwu, and Mgbodile (2016). However, none of these studies focused on the assessment of the nexus between internally generated revenue and budget implementation at state level. Moreso, attempt has not been geared toward disaggregating internally generated revenue and finding the relative impact of each of the disaggregated subsets on budget implementation measured in quantitative term. Based on these identified gaps therefore, this study set out to assess the connection between internally generated revenue and budget implementation in Ekiti state, disaggregating internally generated revenue into taxes, fines and fees, licenses, earnings and sales, as well as interest and dividend and quantifying budget implementation in terms of expenditure implementation fraction (percentage of budgeted expenditure implemented). The broad objective of this study is to examine internally generated revenue on budget implementation in Ekiti State, while the specific objectives are to, examine relative impact of components of internally generated revenue on budget implementation in Ekiti state and to examine the causal relationship between components of internally generated revenue and budget implementation in Ekiti state

\section{Literature Review}

\subsection{Budget and Budget Implementation}

Budget is an important economic instrument of national resource mobilization, allocation and economic management. It is an important economic instrument for facilitating and realizing the vision of government in a given fiscal year. A budget has to be well-designed, effectively and efficiently implemented, adequately monitored and its performance well evaluated. According to Olurankinse (2012), budget can also be viewed as a framework for revenue and expenditure outlays over a specified period usually one year. It is an instrument stipulating policies and programmes aimed at realizing the development objectives of a government. Meigs and Meigs (2004) defined budget as a comprehensive financial plan, presenting the expected route for achieving the financial and operational goals of an organization. Earlier before then, Omolehinwa (2003) viewed budget as the plan of dominant individuals in an organization expressed in monetary terms and subject to the constraints imposed by other participants and the environment indicating how the available resources may be utilized to achieve whatever the dominant individual agreed to be the organization's properties. Recently, budgeting in Nigeria has continued to spring up various controversies as to the modality for preparation and administration in the country due to continuous change in government and consequential change in policy and ideology. Most especially with the understanding that a large percentage of the country population has gotten, this has made them advocate the need to review the size of governance in order to push up the provisions available for more necessary projects. Budgeting and its process in Nigeria continues to be problematic both in the areas of preparation and implementation, hence, the need for adequate control aimed at improving effective resources utilization at the budget implementation stage. Olomola (2009) was of the opinion that the budget process has always been fraught with monumental abuses. Budgeting as it is now understood, originated in the central government of Great Britain. It later developed gradually, as a result of parliament's struggle to obtain control over the finance of the crown. In 1217, it was declared in Magna Charta that "No cottage or aid shall be imposed in the kingdom unless by the common council of realm. After the revolution of 1688, parliament now approved the right to authorized expenditure by the crown as well as taxation apart from items in the sovereign's civil list, which was gradually reduced until it covered only the personal expenses of royal family". (Bendlebury, 2005). A budget is a framework for revenue and expenditure outlays over a specified period usually one year. It is an instrument stipulating policies and programmes aimed at realizing the development objectives of a government. Budgeting and its process in Nigeria remain problematic both in the areas of preparation and implementation, hence, the need for adequate control aimed at improving effective resources utilization at the budget implementation stage. To achieve these objectives, there is need for the introduction of new audit waves such as the value for money audit, due process, cost audit and so on (Obara, 2013). 


\subsection{Internally Generated Revenue (IGR)}

Adam (2006) defined revenue as the fund required by the government to finance its activities. Internally generated revenues (IGR) are revenues or funds generated by states within the Nigerian federation, independent of their share of revenue from the federation account (Deloitte, 2016). IGR for State governments has also been described as revenues that are derived within the state from various sources such as taxes (pay as you earn, direct assessment, capital gain taxes, etc.) and motor vehicle license, among others (Adenugba \& Chike, 2013).There are challenges that have affected IGR collection in the Nigeria, Taxpayers can easily avoid reporting their income to the State (Nigerian Governors Forum, 2015), Many taxpayers in Nigeria do not see payment of tax as their civic responsibility and an obligation to the government. This is because, they believe that on the part of the government, there is no adequate provision of public goods and services that the citizens need as part of their benefit from their tax payment (Okafor, 2012), It is obvious that the principle of fairness and equity in taxation do not apply in the Nigerian tax practice and administration. As a result most tax payers feel unjustifiably levied as there are no benchmarks for proper tax assessment in Nigeria (NGF, 2015), Most tax official lack adequate training and communication skills. The uncivilized manner with which they relate with tax payers does not encourage them to make payments that are due. They approach their job with selfish interest and aggression, thereby giving a taxpayer the option of defending his civic right (NGF, 2015) and Tax laws in Nigeria have not been brought to the layman's understanding. Even among the elites it is still very complicated, such that tax liability becomes a difficult task to compute (Illyas \& Siddiqi, 2010).

\subsection{Theoretical Review}

\subsubsection{Incremental Theory of Budgeting}

"Budgeting is incremental, not comprehensive," Aaron Wildavsky wrote in 1964. "The beginning of wisdom about an agency budget is that it is almost never actively reviewed as a whole every year. Instead, it is based on last year's budget with special attention given to a narrow range of increases or decreases" (Wildavsky, 1964). Wildavsky's work, amplified by Richard Fenno's study of Congress and the appropriations process, became a powerful paradigm not only for budgeting, but for how government makes policy. Charles E. Lindblom's (1959) notions of "muddling though" formed a coherent basis for the theory of budgetary incrementalism. The theory received empirical sup- port from the regression models of Davis, Dempster, and Wildavsky (1966) based on data for federal agencies from 1946 to 1963. Agencies acted as advocates, protecting their budget base and requesting small ("incremental") increases from the previous year. Appropriations subcommittees acted as guardians, making slight reductions in what the agencies requested. These two simple decision rules summarized the process and results of budgeting, revealing the "striking regularities of the budgetary process." (Davis, Dempster, \& Wildavsky, 1966) Annual increases averaging 5 to 10 percent were seen as con- firming incrementalism. The regression models claimed to explain as much as 99 percent of the variance. Incrementalism seemed to meet the test of a paradigm in terms of establishing a broad-based theoretical framework that defined relevant research questions (Kuhn, 1970). Additional variables, such as political and economic factors, were introduced to the empirical models but had little impact on the results (Davis, Dempster, \& Wildavsky, 1974). Incrementalism was extended to governments at other levels and overseas. Studies found incrementalism in cities, states, school districts, various other countries, the United Nations, the World Health Organization, and the International Labor Organization (Anton, 1966; Crecine, 1967; Gerwin, 1969; Cowart et al., 1975; Hoole et al., 1976). It had a dominant position in textbooks on public administration, public policy, and American government. Yet by the late 1970s, incrementalism was under attack and deemed inadequate to explain the rapid changes in budgeting. Incrementalism was a theory that reflected the budgetary environment of the era. In a period of steady economic expansion, government could expand to absorb increasing tax revenues, in other words, "budgeting for growth" (Schick, 1990).

\subsection{Empirical Review}

Demeulenaere, Corvo, Bouckaert, and Meneguzzo, (2013) examined measuring performance based budgeting in Flemish and Italian Municipalities. The study objectively the result elaborated eight interviews performed in both Flemish and Italian municipalities using score analysis. The study concluded by reflecting on the survey and result of the interview done. The study recommended examination and comparison of performance based budgeting practices in other to map the modernization of local government financial management.

Ferry and Eckersley (2013) studied budgeting and governing for deficit reduction in the UK public sector with focus on the Act one comprehensive spending review. specifically the study analyzed the Money war that took place after the financial crisis in the United Kingdom after the 2010 election and how within the spending uncertainty the comprehensive spending review was used to provide a framework for a long term planning approach, which the annuality of the budget can take place within. The study recommended that spending review could be necessary, and that expectations management will be fundamental to at least maintain confidence. 
Onaolapo and Olaoye (2013) appraise factors contributing disparity in budget proposal and implementation. The study examined the behavioural aspect of budget implementation disparity in Ekiti state. The study made of use of primary data sourced using questionnaire administered to thirty five high ranking staff involved in budget preparation and implementation in the state. Data collated were analyzed using student t-test. From the result of the study it was concluded that reason for budget implementation disparity can be explained outside the fact that there is adequate measure to address budget variance, thus it was recommended that government should urgently solve the implementation disparity problem in the state.

Ogujiuba and Ehigiamusoe (2014) examined capital budget implementation in Nigeria taking evidence from the 2012 capital budget using descriptive method of analysis. from the analysis conducted it was established that only $51 \%$ of the total appropriated fund for capital expenditure were utilized as at December $31^{\text {st }} 2012$, thus the study concluded that the observed level of budget implementation is not sufficient to foster rapid economic development and poverty reduction in the country. the study emphasized that challenges responsible for poor implementation of budget in Nigeria include poor conceptualization of the budget inadequacy of implementation plans, non-release or late release of budgeted fund, lack of budget performance monitoring, lack of technical capacity among MDAs e.t.c. thus it was recommended that Nigerian government should formulate realistic as well as credible budget, ensure the release appropriated funds early to Ministries, Departments, and Agencies (MDAs), and also endeavour to strengthen MDAs' technical capacity.

Fuior and Gutan (2015) overviewed conceptual framework and implementation details of budgeting based as it connects to budget performance of Republic of Moldova. The study took a panoramic view of the concept of budget design, budget plan and performance based budgeting, and aligned these concepts to the budget practice of Republic of Moldova. The study adopted a discursive approach to critically overview the conceptual framework that surrounds budgetary allocation of resources to foster achievement of goals. The study recommended that budget programmers should establish budget goals, objectives and performance indicators taking into account the underlining conceptual framework of budgeting

\section{Methodology}

The study employed ordinary least square multiple regression and granger causality analysis to examine the influence of internally generated revenue on budget implementation in Ekiti State. The secondary data were collated from the annual budget of the Ekiti State from 2007 to 2016. The data were collected on Expenditure implementation (EI) being proxy for economic budget implementation, and on the predictor variables which were the Taxes, Fines and Fees, Licenses, Earnings and Sales, Interest and Dividend, Statutory Allocation.

Thus the model of the study is specified in functional and linear forms below:

\section{Functional Form}

Relative impact of components of internally generated revenue on budget implementation

\section{Linear Form}

$$
\mathrm{EI}=\mathrm{f}(\mathrm{TAX}, \mathrm{FF}, \mathrm{LIC}, \mathrm{ES}, \mathrm{ID}, \mathrm{STA})
$$

Relative impact of components of internally generated revenue on budget implementation

$$
\mathrm{EI}=\alpha_{0}+\alpha_{1} \mathrm{TAX}+\alpha_{2} \mathrm{FF}+\alpha_{3} \mathrm{LIC}+\alpha_{4} \mathrm{ES}+\alpha_{5} \mathrm{ID}+\alpha_{6} \mathrm{STA}+\mathrm{U}
$$

Causality between tax and budget implementation

$$
\begin{aligned}
\mathrm{EI}_{\mathrm{t}} & =\sum_{\mathrm{i}=1}^{\mathrm{n}} \delta_{\mathrm{i}} \mathrm{EI}_{\mathrm{t}-\mathrm{i}}+\sum_{j=1}^{\mathrm{n}} \theta_{\mathrm{j}} \mathrm{TAX}_{\mathrm{t}-\mathrm{j}}+\mathrm{U}_{1 \mathrm{t}} \\
\mathrm{TAX}_{\mathrm{t}} & =\sum_{\mathrm{i}=1}^{\mathrm{n}} \delta_{\mathrm{i}} \mathrm{TAX}_{\mathrm{t}-\mathrm{i}}+\sum_{j=1}^{\mathrm{n}} \theta_{\mathrm{j}} \mathrm{EI}_{\mathrm{t}-\mathrm{j}}+\mathrm{U}_{1 \mathrm{t}}
\end{aligned}
$$

Causality between fines $\&$ fees and budget implementation

$$
E I_{t}=\sum_{i=1}^{n} \delta_{i} E I_{t-i}+\sum_{j=1}^{n} \theta_{j} F F_{t-j}+U_{1 t}
$$




$$
\mathrm{FF}_{\mathrm{t}}=\sum_{\mathrm{i}=1}^{\mathrm{n}} \delta_{\mathrm{i}} \mathrm{FF}_{\mathrm{t}-\mathrm{i}}+\sum_{\mathrm{j}=1}^{\mathrm{n}} \theta_{\mathrm{j}} \mathrm{EI}_{\mathrm{t}-\mathrm{j}}+\mathrm{U}_{1 \mathrm{t}}
$$

Causality between licenses and budget implementation

$$
\begin{aligned}
& \mathrm{EI}_{\mathrm{t}}=\sum_{\mathrm{i}=1}^{\mathrm{n}} \delta_{\mathrm{i}} \mathrm{EI}_{\mathrm{t}-\mathrm{i}}+\sum_{\mathrm{j}=1}^{\mathrm{n}} \theta_{\mathrm{j}} \mathrm{LIC}_{\mathrm{t}-\mathrm{j}}+\mathrm{U}_{1 \mathrm{t}} \\
& \mathrm{LIC}_{\mathrm{t}}=\sum_{\mathrm{i}=1}^{\mathrm{n}} \delta_{\mathrm{i}} \mathrm{LIC}_{\mathrm{t}-\mathrm{i}}+\sum_{\mathrm{j}=1}^{\mathrm{n}} \theta_{\mathrm{j}} \mathrm{EI}_{\mathrm{t}-\mathrm{j}}+\mathrm{U}_{1 \mathrm{t}}
\end{aligned}
$$

Causality between earnings \& sales and budget implementation

$$
\begin{aligned}
& \mathrm{EI}_{\mathrm{t}}=\sum_{\mathrm{i}=1}^{\mathrm{n}} \delta_{\mathrm{i}} \mathrm{EI}_{\mathrm{t}-\mathrm{i}}+\sum_{j=1}^{\mathrm{n}} \theta_{\mathrm{j}} \mathrm{ES}_{\mathrm{t}-\mathrm{j}}+\mathrm{U}_{1 \mathrm{t}} \\
& \mathrm{ES}_{\mathrm{t}}=\sum_{\mathrm{i}=1}^{\mathrm{n}} \delta_{\mathrm{i}} \mathrm{ES}_{\mathrm{t}-\mathrm{i}}+\sum_{\mathrm{j}=1}^{\mathrm{n}} \theta_{\mathrm{j}} \mathrm{EI}_{\mathrm{t}-\mathrm{j}}+\mathrm{U}_{1 \mathrm{t}}
\end{aligned}
$$

Causality between interest $\&$ dividend and budget implementation

$$
\begin{aligned}
& \mathrm{EI}_{\mathrm{t}}=\sum_{\mathrm{i}=1}^{\mathrm{n}} \delta_{\mathrm{i}} \mathrm{EI}_{\mathrm{t}-\mathrm{i}}+\sum_{\mathrm{j}=1}^{\mathrm{n}} \theta_{\mathrm{j}} \mathrm{ID}_{\mathrm{t}-\mathrm{j}}+\mathrm{U}_{1 \mathrm{t}} \\
& \mathrm{ID}_{\mathrm{t}}=\sum_{\mathrm{i}=1}^{\mathrm{n}} \delta_{\mathrm{i}} \mathrm{ID}_{\mathrm{t}-\mathrm{i}}+\sum_{\mathrm{j}=1}^{\mathrm{n}} \theta_{\mathrm{j}} \mathrm{EF}_{\mathrm{t}-\mathrm{j}}+\mathrm{U}_{1 \mathrm{t}}
\end{aligned}
$$

WHERE:

$\mathrm{EI}=$ Expenditure Implementation

TAX $=$ Taxes

$\mathrm{FF}=$ Fines and Fees

LIC $=$ Licenses

ES=Earnings and Sales

ID=Interest and Dividend

STA=Statutory Allocation

$\mathrm{U}=$ Stochastic Error Term

$\alpha_{0}, \alpha_{1}, \alpha_{2}, \alpha_{3}, \alpha_{4}, \alpha_{5}$ are parameter estimates corresponding to each of the explanatory variables.

\section{Data Analysis and Interpretation}

This section presented analysis of the relative impact of taxes, fines and fees, licenses, earnings and sales, interest and dividend on budget implementation in Ekiti State, measured in terms of expenditure implementation. Presented in this section are standardized regression estimation result, and post estimation test results for linearity, normality, autocorrelation and heteroscedasticity assumptions.

Regression Estimation: 
Table 1. Regression Estimation Result Dependent Variable: Expenditure Implementation

\begin{tabular}{lllll}
\hline Variable & Coefficient & Std Error & t-statistics & Prob. \\
\hline C & 82.79131 & 4.295097 & 19.27577 & 0.0003 \\
TAX & 4.754741 & 8.713065 & 0.545702 & 0.6232 \\
FF & 0.354370 & 21.88706 & 0.016192 & 0.9624 \\
LIC & 1.312830 & 16.28883 & 0.080597 & 0.8427 \\
ES & 0.166495 & 9.920025 & 0.016784 & 0.9877 \\
ID & 2.478020 & 8.305858 & 0.298346 & 0.7849 \\
STA & 50.44622 & 22.57962 & 2.234148 & 0.1116 \\
\hline
\end{tabular}

Source: Author's Computation (2018)

\section{R-Squared=0.907896}

Adjusted R-Square $=0.723688$

F-statistics $=4.928646$

Prob $($ F-statistics $)=0.009220$

Result presented in table 1 revealed the relative impact of components of internally generated revenue on budget implementation measured in terms of expenditure implementation. As reported in the table all components exert positive impact on expenditure implementation. Relative impact of taxes of expenditure implementation stood at 4.754741 , with probability value of $0.6232>0.05$. Relative impact of fines and fees stood at 0.354370 with probability value of $0.9624>0.05$. Relative impact of licenses stood at 1.312830 , with probability value of $0.8427>$ 0.05 . Relative impact of earnings and sales, as well as interest and dividend stood at $0.166495(\mathrm{p}=0.9877>0.05)$ and $2.478020(p=0.7849>0.05$ respectively. Notably the relative impact of statutory allocation on budget implementation stood at 50.44622, with reported probability value of $0.1116>0.05$. Reported R-square value stood at 0.907896 which implies that about $91 \%$ of the systematic variation in budget implementation measured in terms of expenditure implementation can be explained by component of internally generated revenue such as taxes, fines and fees, licenses, earnings and sales, interest and dividend, as long as statutory allocation is controlled for.

\section{Post Estimation Test:}

Post estimation test conducted in the study include linearity test (using Ramsey Reset Test). Normality test (using Jarque-Bera test), serial correlation test (using LM test) and heteroscedasticity test (using Breusch-Pagan Godfrey test). Summary of the aforementioned post estimations are presented in table 4.4 below

Table 2. Post Estimation Test Result

\begin{tabular}{lll}
\hline Linearity Test & & \\
\hline Statistics & Values & Probability \\
T-statistic & 3.344109 & 0.0790 \\
F-statistic & 11.18306 & 0.0790 \\
Likelihood ratio & 8.85786 & 0.0856 \\
\hline Normality Test & & \\
\hline Statistics & Values & Probability \\
Jarque-Bera Stat & 1.116436 & 0.572228 \\
\hline Serial Correlation LM Test & & \\
\hline Statistics & Values & Probability \\
F-statistic & 0.490249 & 0.71061 \\
\hline Heteroscedasticity Test & & \\
\hline Statistics & Values & Probability \\
F-statistic & 0.992252 & 0.5482 \\
\hline
\end{tabular}

Source: Author's Computation (2018)

Result of Ramsey linearity test presented in table 2 report three statistics including t-statistics, f-statistics and likelihood ratio statistic, alongside their respective probability values. Specifically table 2 reported t-statistics of 3.344109, f-statistics of 11.18306, and likelihood ratio statistics of 8.85786 alongside respective probability values of 0.0790 , 0.0790 and 0.0856 . Hence overview of the reported statistics and their corresponding probability values revealed that there is no enough evidence to reject the null hypothesis that the model is correctly specified. As such the test established that there is linear associationship between expenditure implementation and components of internally generated revenue in Ekit state. Jarque-bera statistics and probability values of the estimated models reported in table 2 stood at 1.116436 , and 0.572228 . The result revealed that there is no enough evidence to reject the null hypothesis that the error term of the estimated model is normally distributed, given the probability value that is greater than 0.05 . Hence 
it is evidence that the error term of the estimated model is normally distributed. Breusch-Godfrey serial correlation LM test result presented in table 2 revealed f-statistics and probability values of 0.490249 and 0.71061 respectively. The statistics showed that there is no evidence to reject the null hypothesis of no serial correlation between successive values of error terms of the estimated models. Hence there is no problem of serial autocorrelation in the estimated models. Also table 3 reported f-statistics and probability values of 4.409169 and 0.1050 . Given the probability of the reported f-statistics, it stands that there is no evidence to reject the null hypothesis of constant variance of the error term (homoscedasticity). Hence the test confirmed that there is no problem of heteroscedasticity in the error term of the estimated models.

Granger causality test:

Table 3. Causal Relationship between Expenditure Implementation and Taxes

\begin{tabular}{lll}
\hline Null Hypothesis: & F-Statistic & Prob. \\
\hline TAX does not Granger Cause EI & 0.22752 & 0.8091 \\
\hline EI does not Granger Cause TAX & 4.40175 & 0.1281 \\
\hline
\end{tabular}

Source: Author's Computation (2018)

Granger causality test result presented in table 3 reflects the causal relationship between taxes as a component of internally generated revenue of Ekiti state and expenditure implementation of Ekiti state. The result reported f-statistics of 0.22752 and 4.40175 alongside probability values of 0.8091 and 0.1281 for the hypotheses tested. The result revealed that there is no causal relationship between taxes and budget implementation in Ekiti state measured in terms of expenditure implementation.

Table 4. Causal Relationship between Expenditure Implementation and earnings and Sales

\begin{tabular}{lll}
\hline Null Hypothesis: & F-Statistic & Prob. \\
\hline ES does not Granger Cause EI & 0.26658 & 0.7824 \\
EI does not Granger Cause ES & 7.72062 & 0.0656 \\
\hline
\end{tabular}

Source: Author's Computation (2018)

Granger causality test result presented in table 4 reflects the causal relationship between earning and sales as a component of internally generated revenue of Ekiti state and expenditure implementation of Ekiti state. The result reported f-statistics of 0.26658 and 7.72062 alongside probability values of 0.7824 and 0.0656 for the hypotheses tested. The result revealed that there is no causal relationship between earnings \& sales and budget implementation in Ekiti state measured in terms of expenditure implementation.

Table 5. Causal Relationship between Expenditure Implementation and Fines and Fees

\begin{tabular}{lll}
\hline Null Hypothesis: & F-Statistic & Prob. \\
\hline FF does not Granger Cause EI & 1.48620 & 0.3560 \\
EI does not Granger Cause FF & 1.95699 & 0.2858 \\
\hline Sor
\end{tabular}

Source: Author's Computation (2018)

Granger causality test result presented in table 5 reflects the causal relationship between fines and fees as a component of internally generated revenue of Ekiti state and expenditure implementation of Ekiti state. The result reported f-statistics of 1.48620 and 1.95699 alongside probability values of 0.3560 and 0.2858 for the hypotheses tested. The result revealed that there is no causal relationship between fines and fees and budget implementation in Ekiti state measured in terms of expenditure implementation.

Table 6. Causal Relationship between Expenditure Implementation and interest and Dividend

\begin{tabular}{lll}
\hline Null Hypothesis: & F-Statistic & Prob. \\
\hline ID does not Granger Cause EI & 0.20293 & 0.8267 \\
EI does not Granger Cause ID & 0.35385 & 0.7278 \\
\hline
\end{tabular}

Source: Author's Computation (2018)

Granger causality test result presented in table 6 reflects the causal relationship between interest and dividend as a component of internally generated revenue of Ekiti state and expenditure implementation of Ekiti state. The result reported f-statistics of 0.20293 and 0.35385 alongside probability values of 0.8267 and 0.7278 for the hypotheses tested. 
The result revealed that there is no causal relationship between interest and dividend and budget implementation in Ekiti state measured in terms of expenditure implementation.

Table 7. Causal Relationship between Expenditure Implementation and Licenses

\begin{tabular}{lll}
\hline Null Hypothesis: & F-Statistic & Prob. \\
\hline LIC does not Granger Cause EI & 0.51629 & 0.6417 \\
EI does not Granger Cause LIC & 0.37414 & 0.7160 \\
\hline
\end{tabular}

Source: Author's Computation (2018)

Granger causality test result presented in table 7 reflects the causal relationship between licenses as a component of internally generated revenue of Ekiti state and expenditure implementation of Ekiti state. The result reported f-statistics of 0.51629 and 0.37414 alongside probability values of 0.6417 and 0.7160 for the hypotheses tested. The result revealed that there is no causal relationship between licenses and budget implementation in Ekiti state measured in term $4 \mathrm{~s}$ of expenditure implementation.

\section{Conclusion and Recommendations}

Investigation conducted in the study revealed that though internally generated revenue components identified in the study trended predominantly upwards over the last ten years, their relative impact on the level of budget implementation is not significant. More so the study established that there is no causal relationship between components of internally generated revenue and budget implementation, thus past values of components of internally generated revenue does not significantly influence the level of budget implementation in the state and vice versa. Based on the discoveries made, the study recommendations that Ekiti State Government should device a new framework for boosting the level of internally generated revenue in the state, in such a way that potential and resources lying unused in the state will be harmonize to foster effective and efficient budget implementation needed for sustaining improved performance and standard of living of the state, Ekiti State government should devise an IT driven revenue mobilization mechanisms to ensure that revenue generated from all sources such as taxes, fines \& fees, licenses, earnings \& sales, interest and dividend are monitored and properly accounted for and Ekiti State government should reduce external borrowing that can culminate into excessive deduction in the statutory allocation, which could dampen the capacity of sustaining efficient level of budget implementation in the state.

\section{References}

Adams, R. A. (2006). Public sector accounting and finance. Lagos, Nigeria: Corporate Publishers Ventures.

Adenugba, A. A., \& Chike, F. O. (2013). The effect of internal revenue generation on Infrastructural development. A study of Lagos State Internal Revenue Services. Journal of Education and Social Research, 3(2), 419-436. https://doi.org/10.5901/jesr.2013.v3n2p419

Alesina, A., Hausmann, R., Hommes, R., \& Stein, E. (1996). Budget Institutions and Fiscal Performance in Latin America. NBER Working Paper Series 394. https://doi.org/10.3386/w5586

Almos, T. (2002). Municipal Budgeting. Canadian Tax Journal revue fiscalecanadienne, 50(1), 181-198.

Anton, T. (1966). The Politics of State Expenditure in Illinois. Urbana: University of Illinois Press, 1966.

Arogundade, K. K., \& Olaoye, F. O. (2016). Impact of State Revenue and Expenditure on Government Budget Performance in Southwest Nigeria. IOSR Journal of Business and Management (IOSR-JBM), 18(4), 21-29.

Asimiyu, G. A., \& Saidi A. M. (2015).Impact Assessment of Public Budget Indicators on the Nigerian Poor. Journal of Economics and Development Studies, 3(3), 71-85.

Bendlebury, A. (2005). Controlling Government Spending: The Ethos, Ethnics and Economics of Expenditure Management. New York, Oxford University Press, 85-102

Coward, A. A., Hansen, T., \& Brofoss, K. E. (1975). Budgetary Strategies and Success at Multiple Decision Levels in the Norwegian Urban Setting. American Political Science Review, 70, 543-548. https://doi.org/10.2307/1959085

Crecine, J. (1976). A Computer Simulation Model of Municipal Budgeting." Management Science, 786-815. https://doi.org/10.1287/mnsc.13.11.786

Davis, M., Dempster, M., \& Wildavsky, A. (1966). A Theory of the Budgetary Process. American Political Science Review, 60, 509. https://doi.org/10.2307/1952969

Davis, M., Dempster, M., \& Wildavsky, A. (1974). Toward a Predictive Theory of Government Expenditure. British Journal of Political Science, 419-452. https://doi.org/10.1017/S0007123400009650 
Deloitte (2016). Internally generated revenue: what are the short term options at State level? Blog.deloitte.com.ng. Retrieved: August 7, 2017.

Edame, G. E., \& Ejue, M. O (2013) Budgeting Role, Infrastructural Development and Economic Growth in Nigeria. European Journal of Business and Social Sciences, 2(6), 1-15.

Ekhator V. E., \& Chima, P. (2015). Budget and Implementation of Public Policy in Nigeria. British Journal of Economics, Management \& Trade. 10(3), 1-8. https://doi.org/10.9734/BJEMT/2015/19707

Ferry, L., \& Eckersley, P. (2013). Budgeting and Governing for Deficit Reduction in the UK Public Sector: Act One 'The Comprehensive Spending Review'. Journal of Finance and Management in Public Services, 10(1), 14-23.

Fuior, E., \& Gutan, V. (2015).The Budgeting based on the Performance: Conceptual Framework and Implementation Details. Economy Transdisciplinarity Cognition, 18(1), 70-83.

Hool, F., Job, B., \& Tucker, H. (1976). Incremental Budgeting in International Organizations. American Political Science Review, 70, 273-301. https://doi.org/10.2307/2110645

Ibanichuka, E. A., \& Oyadonghan, K. J. (2014) A Critique On Cash Basis Of Accounting And Budget Implementation In Nigeria. European Journal of Accounting Auditing and Finance Research, 2(3), 69-83.

Illyas, M., \& Siddiqi, M. W. (2010). The impact of revenue gap on economic growth: A case of Pakistan. International Journal of Human and Social Sciences, 5(11).

Kuhn, T. (1970). The Structure of Scientific Revolutions. Chicago: University of Chicago Press, 1970.

Meig, W., \& Meig, F. (2004). Accounting the Basic Business Decision New York, USA, MCGraw-Hill Book Company, $51-68$

Miekatrien, S., \& Geert, B. (2006). The impact of performance budgeting on the role of parliament: a four country study. Paper presented at the $2^{\text {nd }}$ Transatlantic Dialogue workshop 1: the performance of performance budgeting, Leuven.

Nigeria Governors' Forum. (2015). Internally generated revenue of Nigerian States-Trends, Challenges and options. www.nggovernorsforum.org.

Obara, L. C (2013). Budget Preparation and Implementation in the Nigerian Public Sector. Research Journal of Finance and Accounting, 4(16), 50-54.

Ogujiuba, K. K., \& Ehigiamusoe, K. (2014).Capital Budget Implementation in Nigeria: Evidence from the 2012 Capital Budget. Statistics \& Population Studies, South Africa, 8(3). https://doi.org/10.5709/ce.1897-9254.147

Ojo, E. O. (2012.) Constraints on Budgeting and Development Plan Implementation in Nigeria: an Overview. European Journal of Sustainable Development, 1(3), 445-456.

Okafor, R. G. (2012). Tax Revenue Generation and Nigerian Economic Development. European Journal of Business and Management, 4(19), 49-56.

Okpala, K. E. (2014). Medium Term Expenditure Framework and Budget Effectiveness in Nigeria. International Journal of Innovation and Scientific Research, 4(1), 26-32.

Oladele, P. O., \& Olaoye, F. O. (2016). Dynamic Analysis of Financial Control and Government Budget Performance in Southwest Nigeria. International Journal of Economics, Commerce and Management, 4(4), 625-639.

Olomola, A. S. (2009). Strategies and Consequences of Budgetary Reforms in Nigeria, Paper for Presentation at the 65th Annual Congress of the Institute of International Public Finance (IIPF), Cape Town, South Africa.

Olowolaju, P. S., Ajibola, O., Akintoye, I. R., \& Falayi, I. (2014). Federal Government Statutory Fund Allocation to States in Nigeria, West Africa: Any Reasonable Story to Tell. American International Journal of Social Science, 3(4), 152-164.

Olurankinse, F., Yabugbe, P. O., \& Ibadin, L. A. (2012). Budgeting as a Tool for Control and Performance Evaluation in the Public Sector. Limited- Lagos: Heinemann.

Omolehinwa, E. (2003). Government Budgeting in Nigeria, Lagos, Pumark Nig Ltd, 1-14.

Omotoso, F. (2009). Administrative problem of state creation in Ekiti state Nigeria. African Journal of Political Science and International Relations, 3(3), 107-116. https://doi.org/10.4314/afrrev.v3i5.51139

Onaolapo, A. R., \& Olaoye, F. O. (2013) Appraisal of The Factors Contributing Disparity In Budget Proposal And Implementation. Arabian Journal of Business and Management Review (OMAN Chapter), 2(11).

https://doi.org/10.12816/0002334 
Onyiah, I. A., Ezeamama, N. C., Ugwu, J. N., \& Mgbodile, C. C. (2016). Nigerian Budget Implementation and Control Reforms: Tool for Macro Economic Growth. British Journal of Economics, Management \& Trade, 11(2), 1-13. https://doi.org/10.9734/BJEMT/2016/19556

Samuel, C. U., \& Wilfred, I. U. (2009). Problems and Prospects of Budgeting and Budget Implementation in Local Government in Nigeria. African Journal of Business Management, 3(12).

Schick, A. (1990). The Capacity to Budget. Washington, D. C.: Urban Institute Press, 1990.

Ugoh, S. C., \& Ukpere, W. I. (2009). Problems and prospects of budgeting and budget implementation in Local Government System in Nigeria. African Journal of Business Management, 3(12), 836-846.

Appendix A: Descriptive Statistics

\begin{tabular}{|c|c|c|c|c|c|c|c|}
\hline & EI & TAX & $\mathrm{FF}$ & LIC & $\mathrm{ES}$ & ID & STA \\
\hline Mean & 82.79 & 3078.89 & 32.58 & 33.59 & 25.99 & 4.364 & 22813.93 \\
\hline Median & 86.47 & 2361.95 & 32.44 & 31.82 & 21.27 & 3.435 & 23805.19 \\
\hline Maximum & 117.41 & 6924.08 & 59.97 & 49.07 & 46.57 & 8.860 & 32387.40 \\
\hline Minimum & 46.38 & 1084.38 & 9.480 & 17.40 & 10.66 & 1.480 & 12334.84 \\
\hline Std.Dev. & 25.83 & 1953.56 & 15.58 & 8.830 & 12.44 & 2.751 & 6918.067 \\
\hline Skewness & -0.133 & 0.77461 & 0.168 & -0.026 & 0.527 & 0.394 & -0.156368 \\
\hline Kurtosis & 1.530 & 2.39296 & 2.316 & 2.724 & 2.088 & 1.556 & 1.823230 \\
\hline Jarque-Bera & 0.929 & 1.15357 & 0.241 & 0.032 & 0.810 & 1.127 & 0.617746 \\
\hline Probability & 0.628 & 0.56170 & 0.886 & 0.983 & 0.666 & 0.569 & 0.734274 \\
\hline Observations & 10 & 10 & 10 & 10 & 10 & 10 & 10 \\
\hline
\end{tabular}

Appendix B: Correlation Matrix

\begin{tabular}{lllllll}
\hline & EI & TAX & FF & LIC & ES & 00 \\
\hline EI & 1.00000 & & & & & \\
TAX & 0.417581 & 1.00000 & & & & \\
FF & 0.288442 & 0.5766595 & 1.00000 & & & \\
LIC & 0.415709 & 0.120153 & 0.4222348 & 1.00000 & & \\
ES & 0.557997 & 0.791508 & 0.5739489 & -0.0179663 & 1.00000 & 1.00000 \\
ID & 0.620045 & 0.2075053 & 0.3292078 & 0.0818222 & 0.5015855 & 0.4842251 \\
STA & 0.778718 & 0.5297142 & 0.7257933 & -0.253595 & 0.6555343 & 1.00000 \\
\hline
\end{tabular}

\section{Copyrights}

Copyright for this article is retained by the author(s), with first publication rights granted to the journal.

This is an open-access article distributed under the terms and conditions of the Creative Commons Attribution license which permits unrestricted use, distribution, and reproduction in any medium, provided the original work is properly cited. 